\title{
Determinants of the Argentine Financial Crisis: Can We Predict Future Crises?
}

\author{
Mete Feridun
}

\begin{abstract}
This article aims at identifying the macroeconomic indicators that account for the Argentine financial crisis. For this purpose, an early warning system (EWS) is built based on a probit model that incorporates six monthly variables spanning the time period between February 1991 and February 2000. The results indicate that the significant indicators are the consumer price index and the ratio of the value of exports to the value of imports. Results further indicate that the predictive power of the model is quite reasonable with a correct prediction probability of 67 percent at 15 percent cutoff level.
\end{abstract}

\section{Introduction}

In the late 1990s, economic and financial crises raged through emerging market economies such as Asia, Mexico, Russia and, more recently, Turkey and Argentina, with devastating economic and social consequences. In today's increasingly interdependent world, finding ways to reduce the risk of future crises has become an international policy challenge of enormous importance. In this respect, a reliable Early Warning System (EWS) is needed to predict financial crises so that policy makers can take pre-emptive measures to mitigate or even prevent them (Wyplosz, 1998).

The objective of this study is to model an early warning system that predicts the likelihood of future currency crises based on a multinomial probit model using monthly Argentine data spanning the time period between February 1991 and February 2000. This paper is structured as follows. Section II reviews the EWS literature. Section III provides background information on the Argentine economy. Section IV presents the data and introduces the methodology used. The last section points out the conclusions that emerge from the study.

\footnotetext{
* The author is a lecturer in finance at Eastern Mediterranean University (Cyprus). The author acknowledges Dr. Gulnur Muradoglu, Senior Lecturer in Finance at Cass Business School - City University London, for her valuable comments, suggestions, and assistance in the course of the study. However, all omissions and errors are the responsibility of the author.
} 


\section{Literature Review}

Literature on financial crises is categorised into three mainstream models, namely first-generation models, second-generation models, and third-generation models. In the "first-generation" models (Krugman 1979; Flood and Garber 1984), a government with persistent money-financed budget deficits is assumed to use a limited stock of reserves to peg its exchange rate and the attempts of investors to anticipate the inevitable collapse generates a speculative attack on the currency when reserves fall to some critical level.

In "second-generation" models (Obstfeld 1994, 1996, Ozkan and Sutherland 1995, Radelet and Sachs 1998, and Wyplosz 1998) policy is less mechanical: a government chooses whether or not to defend a pegged exchange rate by making a tradeoff between short-run macroeconomic flexibility and longer-term credibility. The crisis then arises from the fact that defending parity is more expensive as it requires higher interest rates. Should the market believe that defense will ultimately fail, a speculative attack on a currency develops either as a result of a predicted future deterioration in macro fundamentals, or purely through self-fulfilling prediction (Vlaar, 2000).

The need for third generation models became apparent in the 1990s with the Mexican Tequila crisis of 1994 and the Asian crises of 1997. A number of new approaches have emerged to explain how these crises evolved and how they spread from country to country. Third-generation models (Dooley 1997, Krugman 1998, Radelet and Sachs 1998) are categorised into three different groups such as herd-behaviour, contagion, and moral hazard.

There have been numerous studies in the literature on the determinants of financial crises. Empirical literature on financial crises can be categorised into two separate groups. The first group consists of studies based on a model known as "Signals Approach" which involves observing the behaviour of a number of indicators as they issue signals when they exceed certain threshold values. The second approach is based on a logit or probit model and uses lagged values of early warning indicators as well as a dummy variable to predict crises.

Signals approach was developed by Kaminsky et al. (1998) and consists of a bilateral model where a set of high frequency economic variables during a specified period is compared, one at a time, with a crisis index so that when one of these variables deviates from its normal level 
beyond a specific threshold value prior to a crisis, it issues binary signals for a possible currency crisis. Signals model devised by Kaminsky et al. (1998) consists of 15 variables with optimal thresholds estimated for each country in relation to percentiles of the distribution of observations of the indicator maximising the correct signals and minimising the false. Their signal horizon is set at 24 months and a currency crisis is defined as a sharp depreciation of the currency or a large decline in international reserves. Crisis index was formed using a weighted average of monthly percentage changes in the exchange rates and reserves with positive and negative weights attached, respectively, in such a way that the two components of the index have equal conditional volatilities. Periods when the index is above its mean by more than three standard deviations are defined as crisis periods. The percentage of correct signals to the percentage of false signals would give an indication of the accuracy of each indicator. Kaminsky et al. (1998) used monthly data of 15 developing and 5 industrial countries from 1970 to 1995 and detected an average of 61 crises during this period. Their findings show that the best indicators are at least twice as persistent as others in crisis periods relative to tranquil periods and that all indicators send the first signal between one year and one year and a half before a crisis starts. Their best indicators, based on noise-to-signal ratio, are the real exchange rate, banking crises dummy, exports, stock prices, and M2/international reserves. Their study also showed that the real interest differential, imports, bank deposits, lending rate/deposit rate have noise-tosignal ratio smaller than 1 .

This model was later improved by Kaminsky and Reinhart (1999), who used the same sample as in Kaminsky et al. (1998). They found that before a crisis episode, several of the indicators began to send stress signals and that the earliest signals sent by the best predictors were between 6 to 18 months before a crisis starts. Their model identified a total of 26 banking and 76 currency crises, 18 of which were twin crises. They found that the occurrence of both types of crises has increased sharply since the early 1980s with only one twin crisis taking place before 1980. In their study Kaminsky and Reinhart (1999) also found that banking and currency crises had common causes with the former usually preceding the latter and following a particular pattern where the peaks of banking crises follows the currency crises.

The signals approach uses information from crisis and non-crisis times and takes the timing of crises explicitly into account. This method makes it possible to evaluate the predictive powers of individual indicators facilitating the establishment of indicator rankings. Therefore, it is well suited for finding vulnerabilities in an economy as it immediately reveals the 
variable that causes the weakness. This enables policy makers to develop prompt policy responses in order to prevent crises. These models work well with small samples and impose no restriction on the number of explanatory variables.

Despite these advantages, in the signals approach, information from each indicator is treated in an inefficient way since all are transformed into dummies. This implies that signals are equally strong regardless of whether an indicator just passes the threshold or exceeds it by a wide margin. This approach is bivariate, in that each indicator is analysed, and optimal thresholds calculated, separately. Due to this nature of the approach, correlations among the explanatory variables are not taken into account, which can affect the optimal thresholds in a negative way when constructing a composite leading indicator. In addition, these models do not allow the application of some standard statistical evaluation methods, such as the significance tests, as they are nonparametric.

Probit and logit models, pioneered by Frankel and Rose (1996), use limited dependent variable models known as probit or logit regressions to identify the causes of crises. In these models, the currency crisis indicator is also modeled as a zero-one variable, as in the signals approach. However, the explanatory variables do not take the form of a dummy variable, but enter the model in a linear fashion. This approach defines a crisis indicator equal to one or zero depending on whether a currency crisis does or does not occur within the specified time period. Frankel and Rose (1996) attempted to find out how international debt structure and external factors affected the probability of currency crises. They used a number of external, internal and foreign macroeconomic variables in a multivariate probit model specified for 105 developing countries, covering annual data from 1971 to 1992. They defined a crisis as at least $25 \%$ depreciation of the nominal exchange rate that also exceeds the previous year's depreciation level by at least $10 \%$ and constructed a dummy crisis variable according to that rule. Results of their model indicate that the overall explanatory power of the mode1 is quite low with a pseudo R2 measure of around $20 \%$ for all specifications. According to the same results, current account and budget deficits are insignificant as well as most of debt composition variables, except for foreign direct investment. A fall in this variable by one percent of the debt is associated with a $3 \%$ increase in the probability of a crash. Results of their model suggest that the probability of a crisis increases when output growth and reserves are low, and domestic credit growth, external debt and foreign interest rates are high. They also found that the probability of a crash is higher during recessions and when the ratio of foreign direct investment to total debt is low. 
Sachs, Tornell and Velasco (1996) also used a probit model to analyse currency crises, particularly the Mexican Tequila Crisis of 1995, using a sample of 20 emerging countries that were vulnerable to the contagion effect after the 1994 Mexican crisis. They tried to answer the question as to which countries are most likely to suffer serious attacks in the event of a change in the global environment rather than identifying the timing of crises. They used the weighted sum of the percent decrease in reserves and the percent depreciation of the exchange rate from November 1994 to April 1995 as their crisis index. They found that crises happened only in the countries with weak fundamentals such as low reserves, fragile banking systems and overvalued exchange rate. They found that short-term capital inflows do not matter when reserves and fundamentals are strong whilst government consumption and current account deficits matter only in the countries with weak fundamentals and weak reserves.

Berg and Pattillo (1999) tested models offered by Kaminsky, Lizondo and Reinhart (1998), Frankel and Rose (1996) and Sachs, Tornell, Velasco (1996) to see if these models could predict the Asian crisis using information available at the end of 1996 . They found that the models offered by Sachs, Tornell, Velasco (1996) and Frankel and Rose (1996) were ineffective in forecasting the Asian crisis. The Kaminsky, Lizondo and Reinhart (1998) model, on the other hand, proved to be successful. Crisis probabilities generated by this model for the period between May 1995 and December 1996 were statistically significant predictors of actual crisis occurrence over the following 24 months. Besides, the forecasted cross-country ranking of crisis severity provided by this model is a significant predictor of the actual ranking. Berg and Pattillo (1999) also found out that in all three approaches, the probability of a currency crisis increases when domestic credit growth is high, the real exchange rate is overvalued relative to trend, and the ratio of M2 to reserves is high.

In a recent study, Komulainen and Lukkarila (2003) examined the causes of financial crises in 31 emerging market countries during 1980-2001 using a probit model based on 23 variables. Their findings show that financial crises occur together with banking crises and an increase in private sector liabilities, public debt, foreign liabilities of banks, unemployment, inflation, and US interest rates raises the probability of a crisis. Table 1 summarises the empirical literature on early warning systems. 
Table-1: Literature Review on Early Warning Systems

\begin{tabular}{|c|c|c|c|c|c|c|}
\hline Study & $\begin{array}{l}\text { Kaminsky, } \\
\text { Lizondo, } \\
\text { Reinhart } \\
\text { (1998) }\end{array}$ & $\begin{array}{l}\text { Sachs. } \\
\text { Tornell, } \\
\text { Velasco } \\
\text { (1996) }\end{array}$ & $\begin{array}{l}\text { Kaminsky, } \\
\text { Reinhart (1999) }\end{array}$ & $\begin{array}{l}\text { Berg, Patillo } \\
\text { (1999) }\end{array}$ & $\begin{array}{l}\text { Franke1, } \\
\text { Rose (1996) }\end{array}$ & $\begin{array}{l}\text { Komulainen } \\
\text { and } \\
\text { Lukkarila } \\
\text { (2003) }\end{array}$ \\
\hline Approach & $\begin{array}{l}\text { Signals } \\
\text { approach }\end{array}$ & $\begin{array}{l}\text { Probit } \\
\text { model }\end{array}$ & $\begin{array}{l}\text { Signals } \\
\text { approach }\end{array}$ & $\begin{array}{l}\text { Both } \\
\text { approaches }\end{array}$ & $\begin{array}{l}\text { Probit } \\
\text { Mode1 }\end{array}$ & Probit Model \\
\hline Data & $\begin{array}{l}1970-1975 \\
\text { monthly } \\
\text { data from } \\
15 \\
\text { developing } \\
\text { and } 5 \\
\text { industrial } \\
\text { countries }\end{array}$ & $\begin{array}{l}\text { Monthly } \\
\text { data from } \\
20 \\
\text { emerging } \\
\text { markets. }\end{array}$ & $\begin{array}{l}\text { Same sample as } \\
\text { Kaminsky, } \\
\text { Lizondo, } \\
\text { Reinhart (1998) }\end{array}$ & $\begin{array}{l}\text { Same } \\
\text { variables as } \\
\text { Kaminsky, } \\
\text { Lizondo, } \\
\text { Reinhart } \\
\text { (1998) plus } \\
\text { M2/reserves } \\
\text { and CA/GDP }\end{array}$ & $\begin{array}{l}1971-1992 \\
\text { annual data } \\
\text { from } 105 \\
\text { developing } \\
\text { countries }\end{array}$ & $\begin{array}{l}\text { 1980-2001 } \\
\text { monthly data } \\
\text { from } 31 \\
\text { emerging and } \\
\text { developing } \\
\text { countries }\end{array}$ \\
\hline $\begin{array}{l}\text { Crisis } \\
\text { Index }\end{array}$ & $\begin{array}{l}\text { Weighted } \\
\text { average of } \\
\text { exchange } \\
\text { rate and } \\
\text { reserve } \\
\text { changes } \\
\text { with a } \\
\text { threshold } \\
\text { of mean +3 } \\
\text { standard } \\
\text { deviation. }\end{array}$ & $\begin{array}{l}\text { Weighted } \\
\text { sum of } \\
\text { percent } \\
\text { decrease } \\
\text { in reserves } \\
\text { and the } \\
\text { percent } \\
\text { depreciati } \\
\text { on of the } \\
\text { exchange } \\
\text { rates }\end{array}$ & $\begin{array}{l}\text { Weighted } \\
\text { average of } \\
\text { exchange rate } \\
\text { changes and } \\
\text { reserves }\end{array}$ & $\begin{array}{l}\text { Same as } \\
\text { Kaminsky, } \\
\text { Lizondo, } \\
\text { Reinhart } \\
(1998)\end{array}$ & $\begin{array}{l}\text { Exchange } \\
\text { rate change } \\
\text { over } 25 \%, \\
\text { at least } \\
10 \% \text { higher } \\
\text { than } \\
\text { previous } \\
\text { year }\end{array}$ & $\begin{array}{l}\text { Equally } \\
\text { weighted } \\
\text { exchange rate } \\
\text { depreciation } \\
\text { and loss of } \\
\text { reserves with a } \\
\text { threshold of }+2 \\
\text { standard } \\
\text { deviations }\end{array}$ \\
\hline Results & $\begin{array}{l}\text { Significant } \\
\text { variables } \\
\text { include } \\
\text { real } \\
\text { exchange } \\
\text { rate, } \\
\text { exports, } \\
\text { banking } \\
\text { crises } \\
\text { dummy, } \\
\text { stock } \\
\text { prices, } \\
\text { M2/inter- } \\
\text { national } \\
\text { reserves }\end{array}$ & $\begin{array}{l}\text { Crises } \\
\text { happen in } \\
\text { countries } \\
\text { with weak } \\
\text { fundamen- } \\
\text { tal, low } \\
\text { reserves, } \\
\text { fragile } \\
\text { banking } \\
\text { systems, } \\
\text { overvalued } \\
\text { exchange } \\
\text { rate }\end{array}$ & $\begin{array}{l}\text { Detected } 76 \\
\text { currency, } 26 \\
\text { banking, and } \\
18 \text { twin crises. } \\
\text { Found that } \\
\text { banking and } \\
\text { currency crises } \\
\text { have common } \\
\text { causes }\end{array}$ & $\begin{array}{l}\text { Significant } \\
\text { explanatory } \\
\text { variables } \\
\text { include rea1 } \\
\text { exchange } \\
\text { rate, current } \\
\text { account, } \\
\text { reserve, } \\
\text { export, and } \\
\text { M2/reserves }\end{array}$ & $\begin{array}{l}\text { Significant } \\
\text { variables } \\
\text { include real } \\
\text { exchange } \\
\text { rate, } \\
\text { output, } \\
\text { domestic } \\
\text { credit, } \\
\text { foreign } \\
\text { interest } \\
\text { rates }\end{array}$ & $\begin{array}{l}\text { Significant } \\
\text { variables } \\
\text { include private } \\
\text { sector } \\
\text { liabilities, } \\
\text { public debt, } \\
\text { foreign } \\
\text { liabilities of } \\
\text { banks, } \\
\text { unemployment, } \\
\text { inflation, and } \\
\text { US interest } \\
\text { rates }\end{array}$ \\
\hline
\end{tabular}




\section{Background of the Argentine Economy}

In the 1980s, following the IMF's guidance, Argentina cut tariffs on imports, privatised its state enterprises, reduced social service expenditure, and welcomed multinational corporations. Problems began in the 1990s when policy makers decided to implement a fixed exchange rate linking its peso to the dollar at a rate of one to one (Yildizcan 2001). As a result, when the US dollar became overvalued, the peso became overvalued as well, making exports expensive and imports cheap. This, in turn, increased Argentina's trade deficit, interest rates, level of unemployment and diminished its national production. Hence, Argentina wound up with no choice but to borrow more and more from the IMF in order to maintain a large reserve of dollars to sustain an overvalued currency (Yildizcan 2001).

A thorough analysis of the Argentine economy prior to the recent financial crisis by Eichengreen (2002) reveals that Argentina had suffered extended periods of economic stagnation and high levels of inflation prior to its financial crisis episodes. Then, it pegged their exchange rates as an attempt to stabilise its ailing economy and to bring down inflation. Argentine policy makers chose to implement an inflexible peg by adopting a dollar-based currency board. Further analysis by Eichengreen (2002) reveals that following extended periods of economic instability, Argentina managed to bring inflation down in the context of the exchange rate based stabilisation policy. Then, it experienced a post-stabilisation boom as the reduction in the interest rates toward global levels stimulated the domestic demand, especially for durable and semi-durable consumption goods and private investment. In addition, the volume of exports increased as the economy reached stable levels. However, export growth reached was highly insufficient to finance the buoyant import demands. This rendered the country dependent on capital inflows. As a result, the country made intensive efforts to balance the public-sector accounts and pursued ambitious programmes to privatise the public enterprises. Furthermore, it took steps to strengthen the banking system. However, when crisis hit the country in 2001, the fiscal consolidation movement was incomplete and as Eichengreen (2002) points out, the political support for cuts in public spending was highly fragile and fragmented. In Argentina, political disturbance jeopardised the fiscal and economic adjustment attempts and the trigger of the crisis was the breakdown of support for the fiscal cuts demanded by the Economy Minister Jose Luis Machinea and his political successor, Roberto Lopez-Murphy. The crisis required the immediate assistance of the IMF, which initially rejected a $\$ 1.3$ billion-credit demand by Argentina and allowed its financial crisis to deepen. The IMF finally provided credit to Argentina only after it became completely unable to maintain its peg to the dollar due to the devaluation of the Brazilian Real. 


\section{Data and Methodology}

\subsection{Crisis Definition}

Building an EWS model depends primarily on how we define a crisis. The objective of a crisis definition is to describe large, extraordinary changes in economic variables such as exchange rates, interest rates, or foreign exchange reserves. The literature on predicting currency crises has used the term crisis synonymously with speculative attacks or extreme pressure on the exchange rate. As a result, crisis indices have often been based on identifying sharp changes either in the exchange rate alone, as done by Frankel and Rose (1996), or in the weighted averages of exchange rates and reserves as done by Kaminsky et al (1998).

Essentially, classifying each sample period as being in crisis or not depends on whether or not an index of vulnerability exceeds an arbitrarily chosen threshold. In this study, a crisis episode is considered to occur in a particular month if the month-over-month percentage change in the bilateral exchange rate $^{1}$ is at least $10 \%$. For the purposes of improving the statistical properties of our model, we use a three-month window, i.e. we consider that each crisis episode spans a time period of three months following the month in which the crisis emerged. This practice, from the statistical point of view, strongly increases the number of ones in the sample thereby improving the statistical properties of our probit regressions. In addition, because a large movement in an exchange rate is often followed closely by another or several large movements, some of which may still be part of the crisis associated with the first instance of depreciation (Dowling and Zhuang 2000), we consider only a depreciation episode that takes place 6 months or more after the previous one as a separate crisis. Using this definition and a $10 \%$ month-to-month exchange rate threshold, we identify four separate crises in Argentina during the time period between February 1991 and February 2000 as shown in Table 2 below.

Table-2: Beginning of Crisis Episodes

May 1991

July 1993

January 2000

October 2002

\footnotetext{
${ }^{1}$ Argentine Peso/US dollar
} 


\subsection{Explanatory Variables}

The present study employs six monthly (end-of-month) macroeconomic indicators from Argentina spanning the time period between February 1991 and February 2000. All data are obtained from DataStream and are transformed into natural logarithms to achieve mean-reverting relationships and to make statistical testing procedures valid. We follow a methodology where we use the first three crisis episodes in Argentina to build a probit model that predicts future crises while we use the last crisis to test our model out-of-sample.

Probit models can accommodate only a limited number of explanatory variables. For our probit model, we have chosen a set of six variables as shown in Table 3. We use the bilateral exchange rate between the domestic currency and US dollar as it is an indicator of competitiveness loss or gain for the countries prior to crisis episodes and, to our knowledge, is used in all EWS models including probit models of Frankel and Rose (1996) and Sachs, Tornell and Velasco (1996) both of which found this variable to be a significant crisis indicator for a number of emerging economies. A monetary policy indicator that is used frequently in the literature and we include in this study is domestic credit. This explanatory variable is used as an indicator of the banking sector as well as a monetary policy indicator. As Kaminsky and Reinhart (1998) point out, very high growth rates of domestic credit may serve as a simple indicator of the fragility of the banking system and the higher the domestic credit, the more dependent the real economic activity on the health of the banking system, and the worse the effects of a crisis on the economy.

A pair of explanatory variables used quite frequently in the EWS literature is the level of exports and imports. These variables are used as an indicator of the current account of the countries. Jotzo (1999) points out that declining volume of exports can be considered as an indication of competitiveness loss of a country, possibly caused by an overvalued domestic currency. Frankel and Rose (1996) used import and export growth rates separately in their probit model. In this study, we use the ratio of export values to the import values instead for the purposes of keeping the number of explanatory variables in our model at a minimum thereby diminishing the risk of multicollinearity. Another important indicator used in our model is the money supply M1. As Eichengreen et al (1995) point out, M1 is a measure of liquidity, and its growth indicates excess liquidity, which may invoke speculative attacks on the currency thus leading to a currency crisis. This suggestion is also supported by Dowling and Zhuang (2000) who affirm that rapid growth in credit induced by excessive monetary expansion have historically been associated with currency and banking crises in many countries. 
Literature on EWS also uses market index frequently as an indicator of the market sentiment prior to crises. Frankel and Rose (1996) used index of equity prices as a real sector indicator in their probit model. Following this reasoning, we include Argentine stock market indices in our model. The last indicator that we employ is the consumer price index, which is a common inflation measure that has not been used widely in the literature.

Table-3: Explanatory Variables and Definitions

\begin{tabular}{|c|c|c|}
\hline Variable & Symbol & Explanation \\
\hline $\begin{array}{l}\text { Stock } \\
\text { Market } \\
\text { Index }\end{array}$ & $\mathrm{M}$ & $\begin{array}{l}\text { Argentine monthly stock market indices. Used as a } \\
\text { real sector indicator showing the reaction of the } \\
\text { market prior to crises. }\end{array}$ \\
\hline $\begin{array}{l}\text { Exchange } \\
\text { Rate }\end{array}$ & $\mathrm{X}$ & $\begin{array}{l}\text { Bilateral monthly US dollar exchange rates for the } \\
\text { Argentine Peso. (AP/USD, so that an increase } \\
\text { denotes depreciation of the domestic currency) } \\
\text { Used as an indicator of competitiveness loss or gain } \\
\text { of the country prior to crises. }\end{array}$ \\
\hline $\begin{array}{l}\text { Exports/ } \\
\text { Imports }\end{array}$ & EXIM & $\begin{array}{l}\text { Monthly export values divided by the log returns } \\
\text { of monthly import values. Used as an indicator of } \\
\text { the current account of the country. }\end{array}$ \\
\hline $\begin{array}{l}\text { Money } \\
\text { Supply }\end{array}$ & M1 & $\begin{array}{l}\text { Monthly Argentine money supply M1. Used as an } \\
\text { indicator of monetary policy and liquidity. }\end{array}$ \\
\hline $\begin{array}{l}\text { Domestic } \\
\text { Credit }\end{array}$ & $\mathrm{DC}$ & $\begin{array}{l}\text { Monthly Argentine domestic credit as a percentage } \\
\text { of GDP. Used as an indicator of the banking sector } \\
\text { as well as a monetary policy indicator. }\end{array}$ \\
\hline $\begin{array}{l}\text { Consumer } \\
\text { Price } \\
\text { Index }\end{array}$ & CPI & $\begin{array}{l}\text { Monthly Argentine consumer price index. Used as } \\
\text { an indicator of inflation. }\end{array}$ \\
\hline
\end{tabular}

For individual variables, a positive coefficient means that an increase in this explanatory variable will cause an increase in dependent variable, that is, dummy dependent variable close to 1 . A negative coefficient, on the other hand, would mean that a decrease in this variable would cause a decrease in the likelihood of a crisis with the dummy dependent variable close to 0 . Table 4 summarises the expected signs of the variables as well as the economic rationales behind these expectations. 
Table-4: Expected Signs of the Coefficients

\begin{tabular}{|c|c|c|}
\hline Variable & Sign & Explanation \\
\hline CPI & + & $\begin{array}{l}\text { It is common sense that increased inflation would make a } \\
\text { country more vulnerable to financial crises. }\end{array}$ \\
\hline $\mathrm{X}$ & - & $\begin{array}{l}\text { Berg et al (1999) point out that currency overvaluation } \\
\text { could lead to deteriorations in the current account and } \\
\text { have historically been associated with currency crises. }\end{array}$ \\
\hline EXIM & - & $\begin{array}{l}\text { According to Dowling and Zhuang (2000), weak exports } \\
\text { and excessive imports usually lead to deteriorations in } \\
\text { the current account and have often been associated with } \\
\text { currency crises. }\end{array}$ \\
\hline M1 & + & $\begin{array}{l}\text { According to Eichengreen et al (1995) growth of M1 } \\
\text { indicates excess liquidity, which may invoke speculative } \\
\text { attacks on the currency thus leading to a currency crisis. } \\
\text { Besides, Dowling and Zhuang (2000) point out that } \\
\text { crises historically have been linked to rapid growth in } \\
\text { credit induced by excessive monetary expansion in many } \\
\text { countries. }\end{array}$ \\
\hline DC & + & $\begin{array}{l}\text { Kaminsky and Reinhart (1998) point out that high levels } \\
\text { of domestic credit indicate the fragility of a banking } \\
\text { system, thus leading to banking and financial crises. }\end{array}$ \\
\hline M & - & $\begin{array}{l}\text { According to Kaminsky and Reinhart (1998) recessions } \\
\text { and a bust in asset price bubbles often precede banking } \\
\text { and currency crises }\end{array}$ \\
\hline
\end{tabular}

\subsection{Probit Model}

A probit model is set up using lags of the explanatory variables. In this study, one-, two-, and three-month lagged values are initially used in the same regression to identify significant and insignificant variables, and in case of significant variables, to distinguish the most significant lags, i.e. the lags with the highest Z-statistic or lowest p-value. These variables are then used as early warning indicators in the final probit model after removing the insignificant ones. This is done using a backward stepwise ${ }^{2}$ regression, which starts with including all variables and their three lags, in our model (including their three

\footnotetext{
${ }^{2}$ This method assumes that some input variables in the regression do not have an important explanatory effect on the outcome. Hence, it is a convenient simplification to keep only the statistically significant terms in the model.
} 
lags). Next, we drop the insignificant variables until we end up with only significant ones. Then, we identify the most significant lag for each variable, and use it in the final probit regression. The probit model is set up as follows:

$$
\begin{array}{ll}
\mathrm{y}_{\mathrm{t}}^{*}=\mathrm{X}_{\mathrm{t}-\mathrm{i}} \beta+\varepsilon_{\mathrm{t}} & \varepsilon_{\mathrm{t}} \sim \mathrm{N}\left(0, \sigma^{2}\right) \\
\text { CRISIS }_{\mathrm{t}}=\mathrm{X}_{\mathrm{t}-\mathrm{i}} \beta+\varepsilon_{\mathrm{t}} & \varepsilon_{\mathrm{t}} \sim \mathrm{N}\left(0, \sigma^{2}\right)
\end{array}
$$

where CRISIS ${ }_{t}$ is assumed to be an observable process for each country and its position in time $t$ depends on information available at time $\mathrm{t}-1$ and the random error term $\varepsilon$. We observe $\mathrm{y}$ in such a way that:

$$
\begin{array}{ll}
y=1 & \text { if CRISIS }_{t}>0 \\
y=0 & \text { if CRISIS } \\
t & <0
\end{array}
$$

Therefore, the probability that $\mathrm{y}=1$ is the probability that:

$$
\text { CRISIS }_{t}>0 \text {, or, }
$$

$$
\left.\mathrm{P} \text { CRISIS }_{\mathrm{t}}>0\right)=\mathrm{P}(\mathrm{X} \beta+\varepsilon>0)=\mathrm{P}(\varepsilon>-\mathrm{X} \beta)
$$

$$
\text { where } X=\left(\begin{array}{l}
\mathrm{CPI}_{i} \\
\mathrm{DC}_{i} \\
\mathrm{X}_{\mathrm{i}} \\
\mathrm{EXIM} \\
\mathrm{M}_{\mathrm{i}} \\
\mathrm{M}_{\mathrm{i}}
\end{array}\right) \quad \text { and } \mathrm{i}=1,2,3
$$

As shown in equations (3) and (4), a binary dummy crisis variable is constructed for the financial crises. This dummy variable takes the value of one or zero depending on whether a currency crisis does or does not occur. If the crisis takes place, the dependent variable takes the value of 1 . Otherwise it remains 0 . The dependent variable is then regressed on lagged values of the explanatory variables. 
Mete Feridun 43

\subsection{Properties of Data}

Table 5 below shows the major descriptive statistics for the Argentine explanatory variables ${ }^{3}$.

Table-5: Descriptive Statistics

\begin{tabular}{|c|c|c|c|c|c|c|}
\hline & CPI & DC & EXIM & M1 & $\mathbf{M}$ & $\mathbf{X}$ \\
\hline Mean & 0.002 & 0.006 & 0.561 & 0.007 & 1.092 & 0.014 \\
\hline Median & 0.000 & 0.010 & 0.194 & 0.002 & 0.387 & 0.002 \\
\hline Maximum & 0.153 & 0.085 & 55.989 & 0.126 & 63.827 & 0.701 \\
\hline Minimum & -0.249 & -0.416 & -26.460 & -0.122 & -30.165 & -0.281 \\
\hline Std. Dev. & 0.027 & 0.041 & 6.663 & 0.045 & 7.712 & 0.129 \\
\hline Skewness & -4.729 & -8.087 & 3.566 & 0.327 & 4.506 & 1.617 \\
\hline Kurtosis & 66.758 & 83.706 & 41.000 & 3.371 & 44.038 & 9.791 \\
\hline $\begin{array}{l}\text { Autocorrelatio } \\
\text { n } \\
\text { Coefficient }\end{array}$ & -0.267 & 0.074 & 0.038 & 0.197 & 0.170 & -0.092 \\
\hline Jarque-Bera & 23022.850 & $\begin{array}{l}37544.67 \\
0\end{array}$ & 8284.244 & 3.128 & 8017.479 & 313.509 \\
\hline Probability & 0.000 & 0.000 & 0.000 & 0.209 & 0.000 & 0.000 \\
\hline
\end{tabular}

As can be seen, CPI has the smallest standard deviation and $\mathrm{M}$ has the largest spread. The only variable that has skewness and kurtosis around 0 and 3, respectively, is M1. When we check the autocorrelations of these three variables we see that all have low autocorrelations. The next step is to check the multicollinearity among these variables.

Table-6: Correlation Matrix

\begin{tabular}{lllllll}
\hline & CPI & DC & EXIM & M1 & X & M \\
\hline CPI & 1 & -0.0507 & -0.0172 & 0.0905 & 0.0773 & 0.0223 \\
DC & 1 & 0.0355 & 0.0326 & -0.1726 & -0.0818 \\
EXIM & & & 1 & 0.1285 & 0.0130 & -0.6112 \\
M1 & & & 1 & 0.2890 & -0.0607 \\
& & & & & 1 & -0.0634 \\
M & & & & & & 1 \\
\hline
\end{tabular}

${ }^{3}$ One-month lags

${ }^{4}$ Autocorrelation coefficient of the first lag 
44 The Lahore Journal of Economics, Vol.9, No.2

As can be seen from Table 6, the stock market index and exports/imports are correlated. Therefore we leave the stock market index out because the latter is a relatively more important indicator showing the competitiveness of a country.

\subsection{Empirical Results}

We first build our model for Argentina using a crisis index, as explained before, based on the crisis periods shown in Table 2. As mentioned before, in this section we follow a stepwise regression. This process consists of three steps. Firstly, we use one-, two- and three-month lagged values in the same regression to identify the significant lags. Secondly, we remove the insignificant variables. Finally, we use the most significant lags of the remaining variables to run our concluding regression.

The criteria followed for eliminating insignificant variables is $10 \%$, i.e. variables with p-values higher than $10 \%$ are dropped. In addition, if the probability of each variable is less than $10 \%, 5 \%$, and $1 \%$, we conclude that this variable is significant in explaining financial crises at $10 \%, 5 \%$, and $1 \%$ confidence intervals respectively, meaning that these particular variables play an important role in determining financial crises and can be used in our final probit model. Equation (7) below shows the variables used in the first pass regression.

$$
\begin{aligned}
& \text { CRISIS }_{\mathrm{t}}=\mathrm{b}_{0}+\mathrm{b}_{1} \mathrm{CPI}_{\mathrm{t}-1}+\mathrm{b}_{2} \mathrm{CPI}_{\mathrm{t}-2}+\mathrm{b}_{3} \mathrm{CPI}_{\mathrm{t}-3}+\mathrm{b}_{4} \mathrm{M}_{\mathrm{t}-1}+\mathrm{b}_{5} \mathrm{M}_{\mathrm{t}-2}+\mathrm{b}_{6} \mathrm{M}_{\mathrm{t}-3}+ \\
& \mathrm{b}_{7} \mathrm{X}_{\mathrm{t}-1}+\mathrm{b}_{8} \mathrm{X}_{\mathrm{t}-2}+\mathrm{b}_{9} \mathrm{X}_{\mathrm{t}-3}+\mathrm{b}_{10} \mathrm{EXIM}_{\mathrm{t}-1}+\mathrm{b}_{11} \mathrm{EXIM}_{\mathrm{t}}+\mathrm{b}_{12} \mathrm{EXIM}_{\mathrm{t}-3}+\mathrm{b}_{13} \mathrm{DC}_{\mathrm{t}-1}+ \\
& \mathrm{b}_{14} \mathrm{DC}_{\mathrm{t}-2}+\mathrm{b}_{15} \mathrm{DC}_{\mathrm{t}-3}+\varepsilon
\end{aligned}
$$


Mete Feridun 45

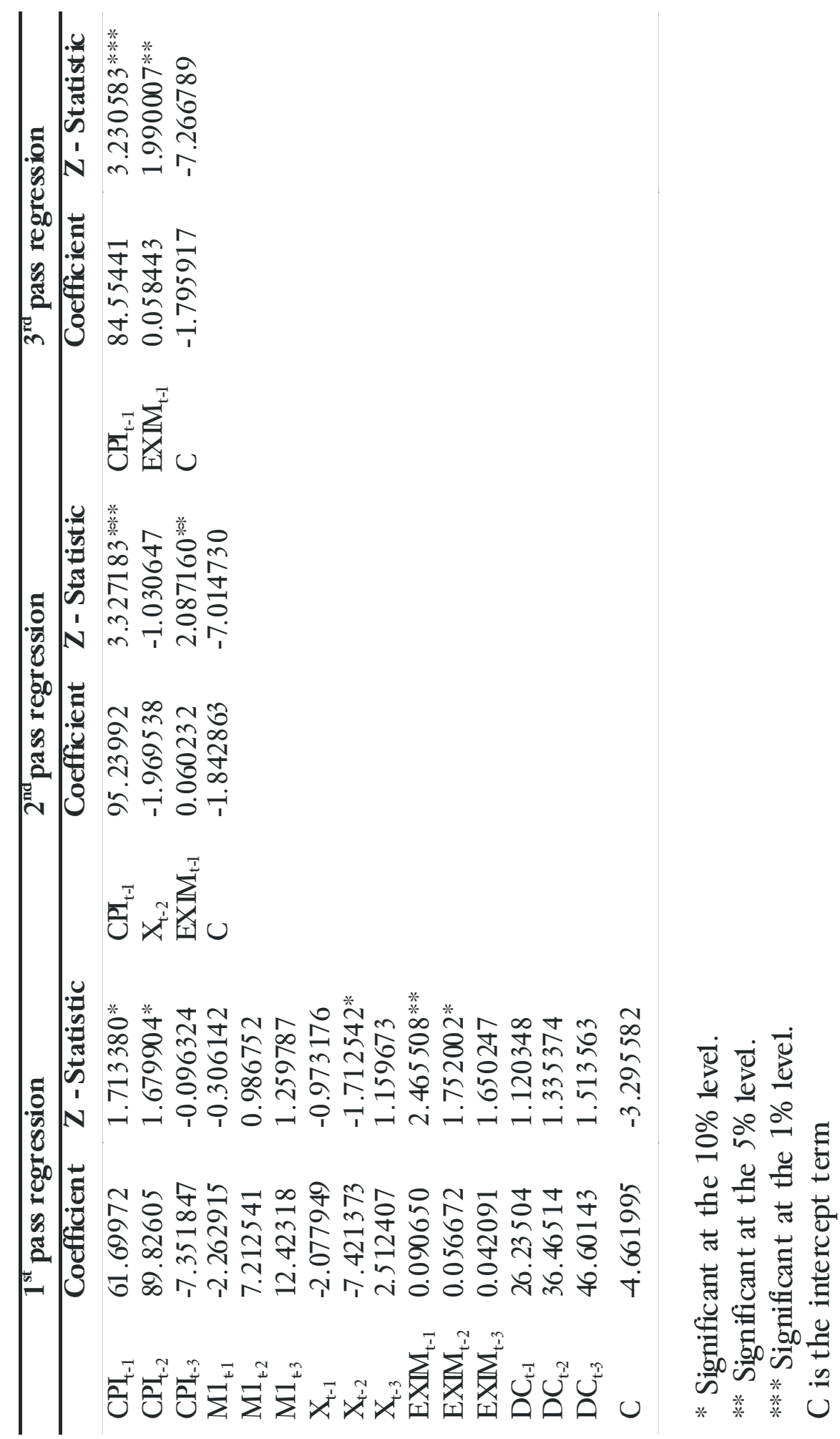


As can be seen in Table 7, DC and M1 are not significant. Therefore, we run a second regression without these variables. We note that $\mathrm{X}$ is not significant at the end of the second regression. Therefore, we run a third regression excluding this variable. As the table indicates, both variables are significant in the final regression. Therefore, we conclude that the only significant variables in explaining the Argentine financial crisis within the time period specified are CPI (one-month lag) and EXIM (one-month lag). As can be seen in Table 7, the sign of CPI is in line with our expectations. However, EXIM, surprisingly, has a positive coefficient. As we have already explained, declining volume of exports is considered an indication of competitiveness loss of a country. Therefore, the sign of EXIM is not in line with our expectations. Table 8 enables us to evaluate the predictive power of this model. We use arbitrary cutoff levels of $30 \%$ and $15 \%$ to see how well it is able to predict the occurrence of financial crises.

Table 8: Prediction Evaluation

\begin{tabular}{lcc}
\hline & Success cutoff $=0.30$ & Success cutoff $=0.15$ \\
\hline Percent Correct & 50.00 & 66.67 \\
Percent Incorrect & 50.00 & 33.33 \\
\hline
\end{tabular}

As Table 8 points out, for this probit model there is $66.67 \%$ and $50 \%$ correct prediction rate at $15 \%$ and $30 \%$ cutoff levels respectively. Outof-sample test also affirms this conclusion. Equation (8) below shows an outof-sample test for the October 2002 crisis in Argentina by using data beyond our sample.

CRISIS $_{\mathrm{t}}=\mathrm{b}_{0}+\mathrm{b}_{1} \mathrm{CPI}_{\mathrm{t}-1}+\mathrm{b}_{2} \mathrm{EXIM}_{\mathrm{t}-1}+\varepsilon$

$=-1.796+84.554(0.0296)+0.058(0.0483)=0.56981$

where ${ }_{t}$ denotes October 2002, $t-1$ denotes September 2002 and, $t-2$ denotes August 2002. As can be seen the result of our model using the above values gives us 0.55981 which is rather away from the dummy variable 1 , thereby failing to indicate a crisis. Consequently, we can conclude that an EWS based on a probit model using the aforementioned variables within the time period specified is only moderately successful in predicting future financial crises. 


\section{Conclusion}

In this study a probit model is built based on monthly data from Argentina. Evidence emerges that the only significant variables are the consumer price index and the ratio of the volume of exports to volume of imports. The positive sign of CPI is in line with our expectations whereas that of export/import ratio is not. The model as a whole is fairly successful in predicting financial crises; at $15 \%$ prediction cutoff, it is able to predict crises correctly with a probability of $67 \%$. However, an out-of-sample test conducted over the 2001 financial crisis of the model also fails to predict the crisis at a reliable level.

Changing the crisis definition according to what is to be warned against and adjusting the sensitivity of the crisis measure according to the needs, preferences, and degrees of risk-aversion of policy makers may improve or worsen the performance of the model. This study constitutes a first step in the construction of an extensive early warning system. The probit model built in this study employs only macroeconomic variables. In order to devise a comprehensive model, qualitative data such as banking crises, contagion, political disturbances, moral hazard, and herding behaviour should also be included in an EWS. 


\section{References}

Berg, A. and C. Pattillo, 1999, "Predicting Currency Crises: The Indicators Approach and an Alternative." Journal of International Money and Finance, Volume. 18.

Berg, A., E. Borensztein, G. M. Milesi-Ferretti, and C. Patillo, 1999, "Anticipating Balance of Payments Crises: The Role of Early Warning Systems.” IMF Occasional Paper. Number 186.

Dooley, M., 1997, “A Model of Crisis in Emerging Markets”, NBER Working Paper. Number 6300.

Dowling. M, Malcolm D. and J. Zhuang, 2000, "Causes of the 1997 Asian Financial Crisis: What More Can We Learn from an Early Warning System Model?” Department of Economics, Melbourne University, Australia Working Paper. Number 123.

Eichengreen, B., 2002, "Financial Crises and What to Do About Them." Oxford University Press.

Eichengreen, B., A.K. Rose, and C. Wyplosz, 1995, "Exchange Rate Mayhem: The Antecedents and Aftermath of Speculative Attacks", Economic Policy, Number 21.

Flood, R. and P. Garber, 1984, "Collapsing Exchange Rate Regimes: Some Linear Example” Journal of International Economics. Volume 17.

Franke1, J. and A. Rose, 1996, "Currency Crashes in Emerging Markets. An Empirical Treatment," Journal of International Economics. Volume 41.

Jotzo, F., 1999, "The East Asian Currency Crises: Lessons for an Early Warning System." Asia Pacific School of Economics and Management Working Papers. APSEM

Kaminsky, G., Lizondo, S. and C. Reinhart, 1998, "Leading Indicators of Currency Crises.” IMF Staff Papers. Volume 45.

Kaminsky, G. L., and C.M. Reinhart, 1999, "The Twin Crises: The Causes of Banking and Balance of Payments Problems.” American Economic Review, Vol. 89. 
Komulainen T., J. Lukkarila, 2003, "What Drives Financial Crises in Emerging Markets” Emerging Markets Review. Volume 4,

Krugman, P., 1979, “A Model of Balance of Payments Crises”, Journal of Money, Credit, and Banking, Volume 11.

1996, “Are Currency Crises Self-Fulfilling?” in Ben Bernanke and Julio Rotemberg (eds.) NBER Macroeconomics Annual, Cambridge MA: MIT Press, pp. 345-78.

1998, "Bubble. Boom, Crash: Theoretical Notes on Asia's Crises" (unpublished) Cambridge. MA: MIT

Obstfeld, M., 1994, "The Logic of Currency Crises" Cahiers Economiques et Monetaires (43): 189-213

_ 1996, "Rational and Self-Fulfilling Balance of Payments Crises", American Economic Review, Vol. 76 (March), pp. 72-81.

Ozkan, F. G. and A. Sutherland, 1995, "Policy Measures to Avoid a Currency Crisis," Economic Journal, Volume105.

Radelet, S., and J. Sachs, 1998, The East Asian Financial Crisis: Diagnosis, Remedies, Prospects. Harvard Institute for International Development.

Sachs, J., A.Torne11, and A.Velasco, 1996, "Financial Crises in Emergin Markets: The Lessons from 1995," Brookings Papers on Economic Activity pp. 147-218.

Vlaar, P., 2000, "Early Warning Systems for Currency Crises.” Papers De Nederlandsche Bank. Number 167.

Wyplosz, C. 1998. "Globalizing Financial Markets and Financial Crises, Paper presented to the Conference on 'Coping with Financial Crises in Developing and Transition Countries,' Amsterdam (16-17 March).

Yildizcan, G., 2001, “Economists: We Won't Become Argentina for the Moment”, Turkish Probe. Issue 465. 